\title{
Adam Smith, the Last of the Former Virtue Ethicists
}

\author{
Deirdre McCloskey*
}

University of Illinois at Chicago

A cademia Vitae, Deventer, The N etherlands

\begin{abstract}
Smith was mainly an ethical philosopher. The recent literature from Knud Haakonssen (1981) through Charles Griswold (1999) and Samuel Fleischacker (2004, pp. $x v, 48-54)$ says so, against the claim by the economists, believed for a long time, that he was mainly an economist in the modern, anti-ethical sense. Taking ethics out of Smith began immediately after his death, in the reactionary era of the French Revolution. Perhaps to assure the British authorities and British public opinion that political economy was not subversive, ethics was omitted. The Cold War inspired similar omissions, and it may be that during the A merican conquest of the field of economics a fear of radicalism supported the anti-ethical reading of Smith.
\end{abstract}

\footnotetext{
${ }^{*}$ With thanks to Gloria Vivenza of the University of Verona for her comments on an earlier draft. Jeffrey Young, editor of the Elgar Companion to Adam Smith, forthcoming, was helpful and encouraging.
} 
But another reason the economists' claim was accepted for so long, against the textual and biographical evidence, is that Smith practiced what was considered for a long time after an obsolete sort of ethical philosophy, known as "virtue ethics." Virtue ethics somewhat mysteriously disappeared from academic circles after the $6^{\text {th }}$ and final and substantially revised edition of Smith's own favorite of his two published books, The Theory of Moral Sentiments $(1759,1790)$. Since 1790 most ethical theory as practiced in departments of philosophy has derived instead from two other books published about the same time, one by Immanuel Kant (1785, for example Frankfurt 2004) and the other by Jeremy Bentham (1789, for example Singer 1993). A third and older tradition of natural rights, which influenced Smith, too, by way of Locke and Pufendorf, finds favor nowadays among conservative and Catholic intellectuals (Leo Strauss 1953, John Finnis 1980; cf. Hont and Ignatieff 1983; but then see Fleischacker 2004, pp. 221-226). And the new contractarian theories of Rousseau, Locke, and Hobbes, to which Smith paid little attention, has provided in our time a fourth, related, stream of narrow ethics paired with grand political theory (Buchanan and Tullock 1962, Rawls 1971, N ussbaum 2006).

But the fifth and by far the oldest and broadest stream is the virtue-ethical one. It flowed from Plato and from Aristotle, meandered through the stoics, was mapped by Cicero (44 BC), and was channeled into Christianity by Aquinas (c. 1269-72). As I say, in the late $18^{\text {th }}$ century this ethics of the virtues, viewed until then by most Europeans as the only sensible way to think about good and bad character, was pushed underground, at least in the academic theories of philosophers, re-emerging only in 1958 (Anscombe 1958, Foot 1978, Maclntyre 1981, Nussbaum herself again 1986, Hursthouse 1999). 
The 170 year reign of ethical theories new in the Enlightenment lasted until the frailties of logic without context became clear, in the later Wittgenstein, for example, and in numerous other post-positivist thinkers. Before then "the notion that the mathematical method could be applied to ethics, rendering it a demonstrative science," writes Father Copleston of the proliferation of new ethical theories c. 1710, following the examples of Hobbes and Spinoza, "was ... common, . . partly because of the prestige won by mathematics through its successful application in physical science and partly because it was widely thought that ethics had formerly depended on authority and needed a new rational basis" (Copleston 1959, p. 251). By 1950 the Enlightenment program was in this respect looking frayed, though quite a few decades passed before the news began to reach fields like economics or evolutionary biology. As Isaiah Berlin noted in his very last paper on analytic philosophy, "no abstract or analytic rigor exists out of all connection with historical, personal thought. ... Every thought belongs, not just somewhere, but to someone and is at home in a context ... which is not purely formally described" (Berlin 1950 quoted in Ignatieff 1998, p. 88).

Though Immanuel Kant, to speak of an historical and personal context of thought, knew and appreciated the 1759 edition of TMS in its German translation, Smith even in 1790 knew nothing of Kant's ruminations in far Köningsberg about the duty to follow generalizable ethical maxims. D. D. Raphael and A. L. Macfie note that "the extent to which Smith was influenced by other moral philosophers of his time" was “remarkably small" (1976, p. 10). But Smith did know, and sharply opposed, the reduction of what is good to what causes pleasure, that is, utilitarianism, if not quite in the form of the "chaos of precise ideas" in Bentham's A Fragment on Government, with an 
Introduction to the Principles of Morals and Legislation, published in the year before Smith's death. The utilitarian stream began earlier than Bentham, of course-for example in the writings of Smith's great friend David Hume, though it also has ancient predecessors in the Epicureans, and it had modern ones in figures like Bernard Mandeville (1714), in the extreme form of "license," or for that matter Nicolò Machiavelli, in the extreme form of the virtú of the prince. Smith opposed these. "In the opinion of [Epicurus, Hume, and the like]," Smith noted, "virtue consists in prudence" (TMS, p. 267). "That system. . . which makes virtue consist in prudence only, while it gives the highest encouragement to the habits of caution, vigilance, sobriety, and judicious moderation, seems to degrade equally both the amiable [Hutchesonian] and respectable [stoic] virtues, and to strip the former of all their beauty, and the latter of all their grandeur" (TMS, p. 307).

Since Bentham, however, and especially since the anti-ethical turn in 20th century economics (associated with Pigou, Robbins [at the extreme], Samuelson, and Friedman), the economists have interpreted Smith's praise of the virtue of prudence to mean what the economists meant by virtue, that is: you do uncontroversial good only by doing well. As Frank Knight wrote in 1923, "the nineteenth-century utilitarianism was in essence merely the ethics of power, 'glorified economics'.... Its outcome was to reduce virtue to prudence"(Knight 1923, p. 62). The turn towards prudence-only was renamed in the 1930s the "new" welfare economics, attempting to build judgments about the economy on the supposition that virtue consists in prudence, with justice taken as sheer taste. If all are benefited, or could be benefited, the proposed policy is good. That is all yeknow of ethics, and all ye need to know (see Brown 1994, pp. 165-166 and footnotes for a 
discussion of such an "overly economistic" readings of The Wealth of Nations; and Evensky 2005, Chp. 10, on the “Chicago Smith” vs. the “Kirkaldy Smith').

Smith did praise prudence as a virtue, especially in his book on prudence. For example: "what is prudence in the conduct of every private family can scarce be folly in that of a great kingdom" (WN, IV.ii, p. 457). But in his other published book one can find hundreds of pages in praise also of other virtues, especially temperance; or of justice in the unpublished lecture notes taken by his students in 1762-63 and 1766. And even in $W N$, unless one is pre-committed to seeing its implied hero as merely a confused precursor to Karl Marx's Mister Money Bags or Paul Samuelson's Max U, one can find a good deal of ethical judgment more grown-up than "prudence suffices" or "greed is good."

The actual, Kirkaldy Smith assumed a person with all the needful virtues-in his accounting five of them, namely, love, courage, temperance, justice, and self-interested prudence, too. From about $400 \mathrm{BC}$ to about $1790 \mathrm{AD}$ the moral universe was described in Europe as composed of the Seven Primary Virtues, resulting by recombination in hundreds of minor and particular virtues. The Seven are a jury-rigged combination of the four "pagan" or "cardinal" virtues (courage, temperance, justice, and prudence) and the three "Christian" or "theological" virtues (faith, hope, and love, these three abide).

Jury-rigged or not, they are a pretty good philosophical psychology. The tensions among the seven, and their complementarities, too, can be expressed in a diagram: 


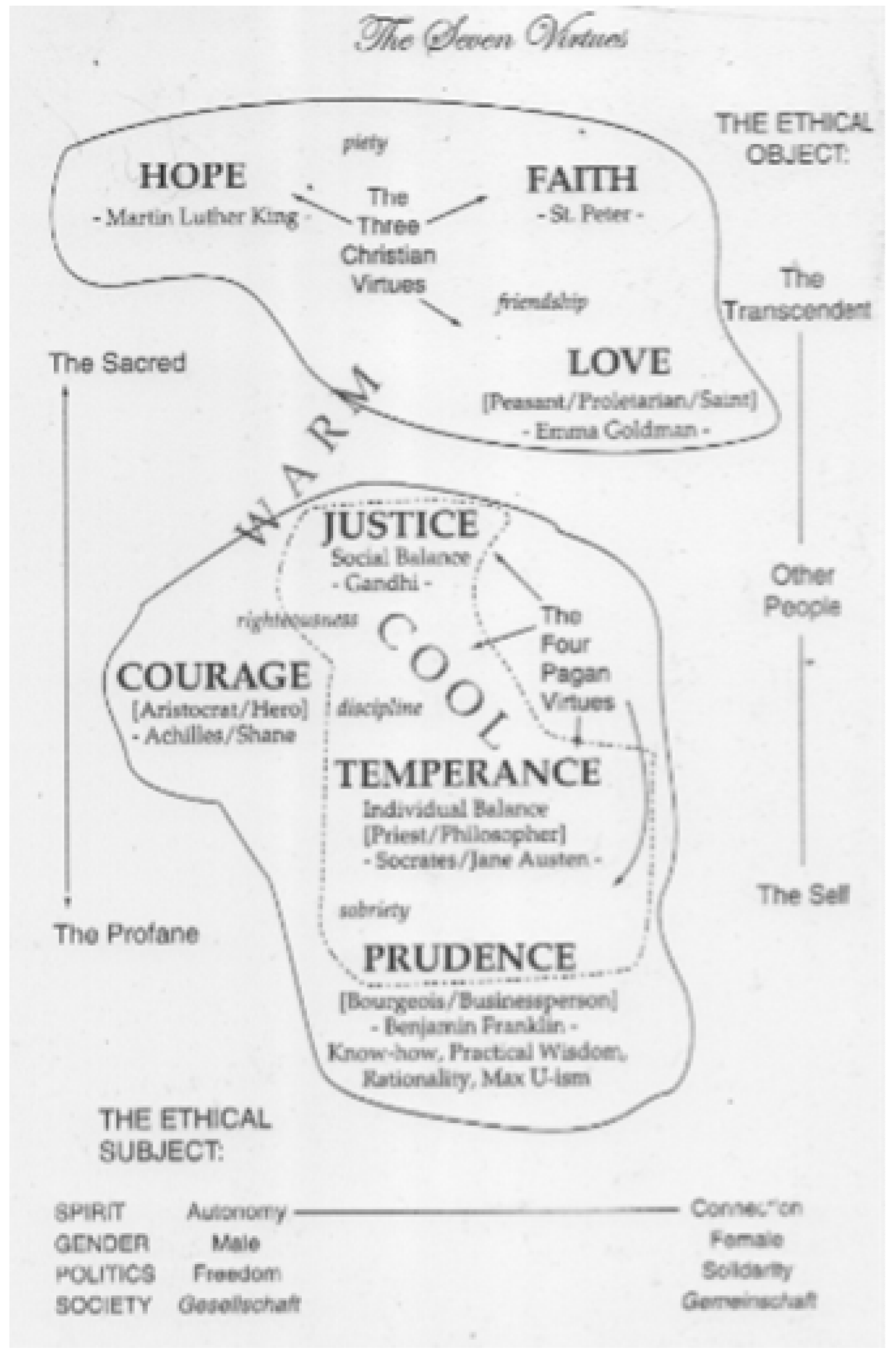


Minor though admirable virtues such as thrift or honesty or purity can be described as combinations of the primary seven. A vice is a notable lack of one or more of them. The seven are in this sense primary colors. They cannot be derived from each other. Blue cannot be derived from red. Contrary to various attempts since H obbes to do so, for example, justice cannot be derived from prudence only. And the other, minor colors can be derived from the primaries. You can't derive red from maroon and purple. But blue plus red does make purple, blue plus yellow make green. The Romantic virtue of honesty, for example, is justice plus temperance in matters of speech, with a dash of courage and a teaspoon of faithfulness.

A quinas was the master of such analyses of virtues and vices. He provides scores of examples in showing that the seven are primary, or in his word "principal." "The cardinal virtues," he declares, "are called more principal, not because they are more perfect than all the other virtues, but because human life more principally turns on them and the other virtues are based on them" (Disputed Questions [1267-72], Art. 1, p. 112). Courage plus prudence yields enterprise, a virtue not much admired by Adam Smith, who recommended instead safe investments in agriculture (Brown 1994, pp. 7, 53, 177). Temperance plus justice yields humility, prominent in Smith's theorizing and in Smith's own character, Fleischacker argues, accounting for his principled modesty in social engineering (Fleischacker 2004, pp. 34-35, 97, 99). Temperance plus prudence yields thrift, which Smith came to believe, erroneously, was the spring of economic growth. 
You can persuade yourself in various ways that the Aquinian Seven are a pretty good philosophical psychology. For example, you can examine each in turn, noting its importance in human flourishing (M cCloskey 2006). Plato did, finding the four in balance in the good person or the good polis. "His own distinctive contribution," writes the classicist Helen North, "is the theory that all virtue depends on the orderly arrangement of faculties within the soul, a condition achieved by the practice of sōphrosynee," that is, temperance, just as in The Theory of Moral Sentiments. Prudence is the executive function, and especially when pursued alone can be thought of as self interest or rationality in attaining ends. Justice is the social balance answering to the personal bal ance of temperance. Thus Plato and the stoic tradition.

Courage is the characteristically male interest, and no wonder therefore that the pagan four el evated it high. The Christians elevated love to primacy, and is therefore construed as feminine. The other Christian additions, hope and faith, are at first puzzling, but less so when hope is understood in secular terms as the forward-looking virtue of imagination, hope, and as the backward-looking virtue of imagination, faith. In other words, hope is the virtue of having a human project. Faith is the virtue of having a human identity. They do not have to be theological. But they do constitute, along with the higher form of love (what the Greeks called agape) the "transcendent.'

Or you can imagine the miseries of a human life without one of the seven, a life without courage, cowering in the corner; or a life without faith, without identity; or a life without hope, left abruptly this afternoon with a bullet to your head.

Or you can ask people how they feel about the virtues. Alan Wolfe found in his surveys and interviews about A merican ethical views in the 1990s that "virtue," 
singular, means little to ordinary Americans, except to arouse irritation at the conservative churches and their recent obsession with sex, sex, sex. But to Wolfe's A mericans the particular named virtues, plural, mean a great deal, provoking calm yet committed discussion. Americans admire, for example, loyalty, that blend of the theological and pagan virtues. And especially they admire honesty-justice and temperance with a dash of courage and a teaspoon of faith. In a broader sense "honesty" is used to mean a bourgeois blend of all the virtues (Wolfe 2002, p. 23ff).

Or you can note that the seven virtues figure in the stories of our culture. The historian of rhetoric Robert Hariman argues that in answering the question what is to be done you can stand with some of the philosophers such as Kant or Bentham, "look for rules." Smith didn't like such rule books. Or you can stand with Sophocles, Thucydides, Adam Smith, and the sophists up to Jane Austen and Iris Murdoch, "look for exemplars," that is, human models of prudence or justice or love (Hariman 2003, p. 7). Smith favored the humanistic teaching of ethics. For example, Plutarch (most of whose ample surviving work is ethical theorizing) was in his Lives steadily ethical, inspiring medieval saints" lives and modern mythologies of national heroes, William Tell to the Blessed JFK. We are still writing the particular virtues, filming them, singing them, retelling the stories in the women's gossip or the men's instant replays. It is not merely the abstract, Aquinian analysis of, say, courage that forms an ethical tradition of resistance to fear. It is the stories of particular courages, in our particular faiths.

Or again you can compare the seven with virtues in other traditions, such as the Confucian. The characterization by Bryan Van Norden of the ethical theory of "the Second Sage" in the Confucian tradition, Mencius (372-289 BC), is startlingly similar to 
the Smith of TMS. Mencius' grounds for opposing utilitarianism, for example, were identical to Smith's: “Suppose someone suddenly saw a child about to fall into a well: everyone in such a situation would have a feeling of alarm and compassion-not because one sought to get in good with the child's parents, not because one wanted fame among their neighbors and friends, and not because one would dislike the sound of the child's cries" (2A 6 in Mencius, quoted in Van Norden 2004, p. 159). The "sprout" of such feeling, to use Mencius' vocabulary, would be the "moral sentiment" posited by Smith. Moral sentiments in Smith, like Mencius' sprouts, are few but powerfully generative of the mature Impartial Spectator. Van N orden calls the growth of a mature ethical character the "affective extension" (p. 150) of the Confucian sprout. The sprout of benevolence, then, is the beginning of a moral sentiment of benevolence à la Smith. "Affective" extension is to be contrasted with what Van Norden calls the "cognitive extension," seen in Kant and Bentham and the like. The focus on affect rather than cognition, I am saying, is very Scottish of Mencius. Again, "righteousness" (yi) in Mencius is "what is appropriate," strikingly similar to the notion of neo-stoic and Ciceronian "propriety" elaborated in Smith (Van Norden 2004, p. 150). Indeed "propriety" is often paired with "righteousness" in the translations from the Chinese. And so forth. We are in a different ethical universe from a Kantian or utilitarian one, but not all that different from virtue ethics in the West.

Or yet again you can predict that if Aquinas's Seven are good places to start a philosophical psychology, then they should show up in the works of psychologists. They do. A recent book published under the auspices of the A merican Psychological Association, edited by Christopher Peterson and Martin E. P. Seligman, Character 
Strengths and Virtues: A Handbook and Classification (2004), lends empirical support to the Seven, at any rate within the European tradition in which they were theorized. It seeks, as the philosopher Peter Danielson says in another connection, the "ethical genome." In 644 big-format text pages, using 2300 citations to the technical literature in clinical and social psychology and related fields, the 40 drafters of the chapters (which Peterson and Seligman then rewrote) present a "manual of the sanities," that is, the "positive psychology" of healthy people. These are not mere assertions but findings, summarizing a gigantic scientific literature, though a literature dealing chiefly with modern Europeans and Americans, not Chinese or Bantu.

What is most relevant here is that the 24 species of strengths they detect are clustered into the encompassing genuses of courage, humanity, justice, and so forththat is to say precisely the "virtues [,] . . . the core characteristics valued by [Western] philosophers and religious thinkers" (Peterson and Seligman 2004, p. 13). The authors number them as six rather than seven, but this is mainly because they lump hope and faith together in one virtue named transcendence, that is, "strengths that forge connections to the larger universe and provide meaning" (p. 30). Five of their "High Six" virtues lay down with ease on the classical Seven - transcendence (that is, faith and hope), courage, humanity (that is, love, which appears in their classification as a "character strength" within what they view as the wider virtue), justice, and temperance. Smith it appears was on to something.

From the Seven Primary Virtues, I say, A dam Smith chose five to admire especially. Hechose all four of the pagan and stoic virtues of courage, temperance, justice, and prudence. To these he added, as virtue number five, a part of the Christian 
virtue of love, the part which his tradition—such as that of his teacher at Edinburgh, Francis Hutcheson $(1725,1747)$ - called benevolence (though it must be admitted, as Gloria Vivenza points out to me, that Hutcheson's "Iay benevolence" has transcendent features beyond eros and philia). In expositing Plato's system, for example, Smith enumerates the pagan four, "the essential virtue of prudence," the "noble" virtue of courage (TMS, p. 268), "a word [sōphrosynē] which we commonly translate temperance," and "justice, the last and greatest of the four cardinal virtues" (TMS, p. 269). In expositing stoicism he repeats the four, also with approval, speaking of virtue as "wise [that is, practically prudent: Greek phronesis], just, firm [that is, courageous], and temperate conduct" (p. 282). And then a triad of prudence, benevolence, justice: "Concern for our own happiness recommends us to the virtue of prudence; concern for that of other people, the virtues of justice and beneficence," "the first ... originally recommended by our selfish, the other two by our benevolent affections" (p. 262). An Impartial Spectator develops in the breast which "in the evening ... often makes us blush inwardly both for our ... inattention to our own happiness, and for our still greater indifference and inattention, perhaps, to that of other people" (p. 262).

Smith particularly admired what Hume had called the "artificial" virtues, the three on which any society must rest, namely, temperance, prudence, and justice. $\mathrm{His}$ admiration shows in his life plan to write a great, thick book about each: temperance is the master virtue of TMS, prudence of $W N$, and justice (though not only: TMS, p. 342) was to be that of a treatise on jurisprudence, never completed.

The other two virtues of theSmithian five were courage in, say, entrepreneurship and love in, say, family arrangements. These stood apart from Smith's central concerns 
for temperance, prudence, and justice. Contrary to what the men in Adam Smith neckties believe, Smith detested buccaneer capitalism, with its emphasis on manly but imprudent courage. And as feminist students of the matter have noted, Smith did not much emphasize family love. Although he expected his dinner from the regard to their self interest of the butcher, the brewer, or the baker, Smith neglected to observe that he expected it, too, from the love of Mrs. Smith the elder in arranging to cook it.

Smith made his virtue-ethical approach clear enough in his works generally and in TMS even in its 1759 edition. But he made it most clear at the end of his life, in a Part VI added 31 years after the first edition. "I have inserted," he wrote on 2 February, 1789 to his publisher, apologizing for delays, "a complete new sixth part containing a practical system of morality, under the title of the Character of Virtue" (Smith, Correspondence, p. 320). Section I of the new Part is an encomium to The Prudent Manthus prudence. Section II is an analysis of benevolence in an expanding circle outward from self to country, taken of course, as was natural at the time, from the male point of view - thus a limited and secular form of love.

And then Smith embarks on a concluding, climactic Section III, "Of SelfCommand," which has al ways been the master virtue in his book. "The man who acts according to the rules of perfect prudence, of strict justice, and of proper benevolence [love, that is] may be said to be perfectly virtuous" (p. 237). That accounts for three of the seven primary virtues-prudence, justice, and love. But suppose the man in question knows that he should act with prudence, justice, and love, but can't bring himself to do it? "The most perfect knowledge, if it is not supported by the most perfect self-command, will not always enable him to do his duty." "Extravagant fear and 
furious anger," to take one sort of passion, "[are] often difficult to restrain even for a single moment" (p. 238). The "command" of fear and anger was called by the ancients "fortitude, manhood, and strength of mind," which is to say the cardinal pagan virtue of courage. "The love of ease, of pleasure, of applause, and other selfish gratifications... often mislead us." The ancients called the command of these "temperance, decency, modesty, and moderation," that is to say, the cardinal virtue of temperance, so very much admired by the stoics (pp. 338-339; compare pp. 268f, 271).

Smith then elaborates on the virtues of courage (pp. 238-240), temperance (pp. 240), a combined courage and temperance (self-command again, pp. 241-243), love briefly (p. 243), cowardice and courage again (pp. 243-246), and then discusses at length mere vanity as against proper self-esteem, figured repeatedly as temperance in judging oneself (pp. 246-262). He asserts at the beginning of the section that "the principle of self-estimation may be too high, and it may likewise be too low" (p. 246) and ends the section by praising "the man who esteems himself as he ought, and no more than he ought" (p. 261).

Such an analysis of temperance is no great advance on A ristotle's golden mean. But Smith did not seek striking originality in his ethical theory. He was building an ethic for a commercial society, but on the foundation of ethical thought in the West, not on some novelty c. 1710 or 1785 or 1789 . Smith's main contribution to ethical theory in his own estimation was the notion of the Impartial Spectator - 'reason, principle, conscience, the inhabitant of the breast, the man within, the great judge and arbiter of our conduct" (TMS, pp. 294, 137). (Smith's use of dynamic theatrical metaphors such as the "Spectator," by the way, has been emphasized by David Marshall [1986] and 
especially by Charles Griswold [1999]). The argument shows in the book's outline. Smith begins with his own theory in Part I, "Of the Propriety of Action," to which merit (Part II), duty (III), utility (IV), and custom (V) are subordinated. The Spectator is formed at first by upbringing and social pressure but at last evolves into a consciencewhat was much later to be called "inner direction."

Though well expressed, it was a routine piece of virtue ethics. The al ternative and novel systems of prudence-only, or of love-only, or of anything-only, as Smith noted, did not work very well. Specializing a theory of ethics down to merely one of the seven virtues-the economist specializing in prudence only, for example, the theologian in love only-does not do the ethical job. Smith declares himself on the issue early, indeed in the very first clause of his book. "How selfish soever man may be supposed," he begins, and then proceeds to show in the next 330 pages that a specialized selfish account, like the one nowadays so popular with economists and evolutionary psychologists, does not suffice. On the fifth page he attacks prudence-only again: “Those who are fond of deducing all our sentiments from certain refinements of selflove think themselves at no loss to account" for sympathy. The supposed egoist rejoices in expressions of approval of his projects, and is downcast by expressions of disapproval, "but both the pleasure and the pain are al ways felt so instantaneously, and often upon such frivolous occasions [for example in a theatre for the characters portrayed, as he later notes; or in an account of some courageous act in ancient times], that it seems evident that neither of them can be derived from any such self-interested consideration" (TMS, pp. 13-14). And so repeatedly throughout. 
Smith is sometimes viewed as a stoic in the mold of Epictetus (FiŁGibbons 1995; Raphael and Macfie 1976, p. 5-10). But such a view, though importantly true in part, tends to specializehim down to temperance-only. As Raphael and Macfiethemselves put it, "Smith's ethical doctrines are ... a combination of stoic and Christian virtues-or, in philosophical terms, a combination of stoicism and Hutcheson. . . who resolved all virtue into ... a philosophical version of the Christian ethic of love" (TMS, "Introduction," p. 6, italics supplied). Smith certainly admired the "manly" character of stoicism, and he famously remarked in a letter that the atheist H ume faced death "with more real resignation. . . than any whining Christian ever died with pretended resignation to the will of God" (Correspondence, Letter 163, 14August 1776). And I have said that Smith spent a third of his life's creative effort inquiring into the master virtue of TMS, the self-command or temperance-plus-courage so characteristic of a successful stoic. In the old Part VII of TMS, dating from his lectures in the 1750s and included in the first edition, in which he surveys the ancient and a very few of the modern systems of ethics, he spends a mere $4 \frac{1}{2} 2$ pages on Plato and Aristotle together, 5 on Hutcheson recommending benevolence only, $5 \frac{1}{2} 2$ on Epicurus (really on Hume) and 8 on Mandeville recommending prudence only. But he spends fully 21 pages on stoicism according to Zeno, Epictetus, Cicero, Seneca, and Marcus Aurelius , $9^{1 / 2}$ of which are a disquisition on the stoic attitude towards suicide added to the $6^{\text {th }}$ edition, apparently in reply to a notorious essay by Hume.

What Smith mainly took from his readings in stoicism, however, was the system of the virtues. That is, Smith was a virtue ethicist who learned his trade in a stoic school (from which, Fleischacker argues [2004, p. 112], in 1759 he graduated; contrast Raphael 
and Macfie, p. 18, “Smith had [by 1790] acquired an even warmer regard for stoicism'). $\mathrm{H}$ is admiring pages on stoicism are gathered in the $6^{\text {th }}$ edition into the chapter of section VII entitled "Of those Systems which make Virtue consist in Propriety," that is, those attending like his own system to a set of virtues instead of merely to one. And in the section VI added in 1790 he argues against the specialized excesses of stoic insensibility, or what we would now call Buddhist disengagement from the world. He recommends instead an active virtue, "that keen and earnest attention to the propriety of our own conduct, which constitutes the real essence of virtue" (p. 244).

A man following propriety shows in a temperate way all the primary virtues. That is to say, he shows a balance of all them, or selects the sub-set appropriate to the occasion. Not temperance-only. The virtues are not cloistered, but take place in the vita activa. In church on Sunday morning the virtuous person exercises chiefly the virtue of spiritual love, on the dance floor on Saturday night the virtue of self-asserting courage, at her job in the bank Monday through Friday the virtue of careful prudence.

Such, I am claiming, was the ethically plural theme of Smith's very last published writing. His very first, "To the Memory of Mr. William Crauford, Merchant of Glasgow," praised "that exact frugality, that downright probity and plainness of manners so suitable to his profession, [which] joined a love of learning, . . an openness of hand and a generosity of heart, ... and a magnanimity that could support ... the most torturing pains of body with an unalterablecheerfulness of temper, and without once interrupting, even to his last hour, the most manly and the most vigorous activity in a vast variety of business. ... candid and penetrating, circumspect and sincere" (Essays on Philosophical Subjects, p. 262). This is stoicism, perhaps, but in a distinctly virtue-ethical 
key, admiring frugality, probity, plainness of manners, love of learning, generosity of heart, great-heartedness, enduring courage, cheerfulness, candor, penetration, circumspection, and sincerity. It admires in short the bourgeois virtues, all of them, together in a system, just as virtue ethicists recommend.

Vivienne Brown, who supports the notion that Smith thinks as I say in terms of the virtues in TMS, argues that in WN by contrast he cannot be seen as ethical at all. She declares especially that the book "cannot be read as an endorsement of "liberal capitalism"'(1994, p. 53). She argues that the highly "dialogic" character of TMS makes it an ethical work (pp. 188 (195). The two texts are seen as emphasizing two different sets of so-called virtues, in a hierarchy denying in fact the lower set ethical any true ethical standing. "The truly moral virtues of beneficence and self-command in TMS," she writes, "are those that define the moral agent as engaged in a dialogic encounter with the self, a moral process of internal debate that is represented by the metaphor of the impartial spectator." In her reading "the other virtues of justice and prudence'-the main subjects of $W N$ as against TMS - 'are therefore denominated as second-order, ... [eliciting] a certain esteem, ... [but not] truly moral virtues" (p. 208).

It is Brown, not Smith, I would reply, who thus "denominates" prudence and justice as second-order, in aid of downplaying Smith's evident approval of the economic parts of "the liberal plan of equality, liberty, and justice" (WN, p. 664). Brown's ingenious application of Bakhtin's notion of dialogic as against monologic discourse certainly does illuminate the rhetoric of the two books. But speaking of rhetoric, $W N$ was written to influence policy under the control of men who fancied themselves as prudent above all. To be effective rhetorically the book had to follow Smith's own 
advice about anger and indignation in TMS — “before resentment ... can become graceful and agreeable it must be. . . brought down below that pitch to which it would naturally rise than almost every other passion" (TMS, p. 34). A book on "police" would do so.

Nonetheless, Smith's indignation regularly broke out in WN, as Brown admits (Brown 1994, p. 190). WN, as Griswold (p. 260-261) and Fleischacker (throughout) argue, is an ethical book. One can agree with Brown that ethics depends on "a moral process of internal debate." But justice and prudence in Smith are not in fact treated non-dialogically, as Brown to the contrary asserts. In both books Smith gives hundreds of instances of the Impartial Spectator staging an internal debate about even these "second-order" virtues.

I noted the revival of virtue ethics after Elizabeth Anscombe's essay in 1958, "Modern Moral Philosophy." (The revival, by the way, has been led notably by women; ethics is the only part of academic philosophy with a substantially feminine voice, a voice heard with growing volume since the 1950s.) The revival directed attention to the desirability of talking about a set of virtues directly, rather than talking in Enlightenment style only of one allegedly Universal Principle. "It would be a great improvement," wrote Anscombe, "if, instead of 'morally wrong,' one al ways named a genus such as 'untruthful,' ‘unchaste,' ‘unjust'”(Anscombe[1958] 1997, p. 34).

But where does one stop in listing the virtues of, say, truthfulness, chastity, justice, and the like? A list of 170 virtues would be so broad as to be usel ess. The point is worth stressing here because Smith's definite five virtues, and his emphasis on the joint cultivation of the five by the Impartial Spectator, puts him solidly in the older 
tradition of virtue ethics. Some post-1958 virtue ethicists, by contrast, seem to have no definite list in mind, or an embarrassingly long one, a fault which the classical virtue ethics of Plato, Aquinas and Smith avoided.

Modern ethical philosophy has indeed two opposite faults of quantity. The one is to let virtues thus proliferate, leaving us to struggle with the 170 words for "virtues" in the main headings of "Class Eight: Affections" of Roget's Thesaurus (edition of 1962). It would be like recommending as an ethical system the 613 commandments of orthodox Judaism, Hillel's count. The study of Kant and Bentham (or indeed of theTorah) imposes a healthy discipline on such proliferation. But so does the study of Aquinas and the rest of the virtue-ethical tradition, which narrows the list to the Seven Primaries.

And the study of Kant or Bentham or Locke leads, alas, to the other fault of quantity, acknowledging too few virtues to fit the stories of our lives-for example, one virtue only, The Good, or the categorical imperative, or the greatest happiness, or the contract behind a veil of ignorance. It chooses one of the seven, such as prudence or love or justice, to stand for all. Smith's better plan is to stop as Epictetus or A quinas did with a definite yet reasonably comprehensive list of a moderate number of the primary virtues. That way you know better what you are talking about. Five or seven, after all, is a mean among $\mathrm{N}=1$ and $\mathrm{N}=170$ or 613 , if not a particularly golden one.

The clerisy nowadays views Aquinas as Catholic dogma, and therefore as something unnecessary for us Protestant or anti-clerical intellectuals to read. And so the Divine Doctor's seven do not get much of a hearing in secular discussions, even by virtue ethicists. The pioneer Philippa Foot on the contrary argued in 1978 that "Summa Theologica is one of the best sources we have for moral philosophy, and moreover ... St. 
Thomas" ethical writings are as useful to the atheist as to the... Christian believer" (1978, p. 2). She and A lasdair Maclntyre are among the handful of ethical philosophers to realize how very useful Aquinas is, and to take Aquinas" numbering of the virtues seriously. Foot for instance wrote that "nobody can get on well if he lacks courage, and does not have some measure of temperance and wisdom [her word for what Smith and I call prudence], while communities where justice and charity [her word-referring to the King James Bible — for what I call secular love and Smith calls benevolence] are lacking are apt to be wretched places to live, as Russia was under the Stalinist terror, or Sicily under the Mafia" (1978, pp. 2-3). That is five out of the seven virtues, counting from the bottom of the diagram-just the five that Smith selected.

A thol FitzGibbons regards Smith as an enemy of A ristotelianism and of fundamentalist religion (which two FitzGibbon tends to merge), and claims with considerable justice, I have noted, that Smith was a "Ciceronian stoic." My claim is that Smith, if a stoic, was willy-nilly therefore the last of a tradition of virtue ethics dating from A ristotle and perfected by A quinas and practiced by the casuists, whom Pascal and other single-virtue theorists began to assault in the $17^{\text {th }}$ century (Toulmin and Jonsen 1987). The one characterization of Smith emphasizes his stoicism. The other emphasizes the wider technique of ethical pluralism of which St. Thomas Aquinas, the follower of A ristotle, in turn was the student of Plato, is a sophisticated version. Both characterizations can be true.

This is not to say that Smith was a close student of Aquinas or of other Christian thinkers. He does not appear to have read them much. A bout Jesuit casuistry he was scathing, in a passage added in 1790: “Books of casuistry. . . are generally as useless as 
they are commonly tiresome," because they do not change people's dispositions. "With regard to one who is negligent in his [duty], the style of those writings is not such as is likely to awaken him to more attention" (TMS, p. 339). In Smith's time St. Thomas had nothing like the prestige he has acquired from the neo-Thomism initiated in the late $19^{\text {th }}$ century by Pope Leo XIII. In 1759 in a Protestant country even a scholar of Smith's quality was liable to suppose that little could be learned from the "scholastics," which was in the Enlightenment of course a term of contempt. He scorns "a scholastic or technical system of artificial definitions, divisions, and sub-divisions; one of the most effective expedients ... for extinguishing whatever degree of good sense there may be in any moral or metaphysical doctrine" (TMS, p. 291). In the one place where Smith might have noted, if he had known it, that Aquinas unlike the lesser theorists of "the benevolent system" gives full weight al so to the secular and pagan virtues, he does not (TMS, p. 301). Heleaps from "many ancient fathers of the Christian church'—which pointedly leaves out Aquinas, who was medieval, born eight centuries after the death of the last of the "ancient fathers," the last at any rate in Western Christendom, St. Augustine -right to the Reformation, in which the benevolent system "was adopted by several [Protestant] divines of the most eminent piety and learning," and then by Hutcheson, “the most philosophical, . . the soberest and most judicious.'

Smith appears to have had read mere summaries of "the schoolmen," as he called them impatiently, for example using in discussing courage and temperance the Aquinian distinction between the "irascible" emotions (that is, hot, angry emotions; TMS, p. 268) and the "concupiscible" (that is, appetitive; recent English translations of Aquinas" Latin prefer instead "concupiscent'). Smith never quotes or refers to Aquinas 
or any other school man directly by name, and a doctrinal influence is untraceable. The power of such evidence, admittedly, is low, since Smith does not quote anyone much at all. Even David Hume, whose doctrinal influence is pal pable, is not actually quoted in Smith, though often replied to. But anyway Smith, in common with some recent writers-who at this date should perhaps know better-skips over the Aquinian and later Christian syntheses of stoic and theological virtues, courage-temperance-justiceprudence plus faith-hopelove, adding up to seven. N or was Smith even, to speak of the acknowledged root of Aquinas" tradition, a self-conscious A ristotelian. As Fleischacker observes, for example, Smith's egalitarianism and his suspicion of philosophical experts implies a virtue of humility that A ristotle would have found very strange indeed (Fleischacker 2004, p. 74). In Smith's summary history of ethics in TMS the Philosopher gets only two pages, and those pages are focused not on A ristotle's somewhat rambling listing of the virtues but on the doctrine of the Golden Mean, so suitable to an Impartial Spectator.

I am merely arguing that Smith, in sharp contrast to his great contemporaries in ethical theorizing, was a virtues man, a half-conscious follower of Plato and A ristotle and therefore of Aquinas, and al so of the stoics (though they, I repeat, can be accused of a monism of temperance only), in emphasizing a system of multiple virtues-and indeed precisely five of the seven Aquinian virtues. That is to say, he was indeed the last of the former virtue ethicists. Smith puts Plato (in parts), A ristotle, the stoics, and in shadowy form the schoolmen into the tradition of "propriety" as against prudence-for-self or love-for-others. "If virtue. .. does not consist of propriety [which is to say the balance in the soul recommended by Plato, A ristotle, some of the stoics, Aquinas, and Smith 
himself], it must consist either in prudence [thus Smith's friend Hume] or in benevolence [thus Smith's teacher Hutcheson]. Besides these three, it is scarce possible to imagine any other account can be given of the nature of virtue" (TMS, p. 267). All ethics in Smith was divided into these three: propriety, prudence, and benevolence/ love. In choosing the first, the multiple virtues of propriety, he chose to stand with the tradition of Aristotle and Epictetus and Aquinas against the monism of some of Plato's stoic followers (reducing justice and prudence and courage and temperance to The Good) or of Hobbes and early Hume (reducing The Good to prudence only) or of Hutcheson in a late and literally sentimental version of Christianity (reducing all the virtues to love only).

As a virtue ethicist Smith disliked all such reductions. "By running up all the different virtues ... to this one species of propriety [namely, "the most real prudence'], Epicurus indulged a propensity," Smith noted, "which philosophers. . . are apt to cultivate with a peculiar fondness, as the great means of displaying their ingenuity. . . to account for all appearances from as few principles as possible" (TMS, p. 299). It is Ockham's Razor, with which so many male philosophers have cut themselves shaving. Parsimony, after all, is not the only intellectual virtue. In his very method Smith recommends a balance of the virtues, historical relevance balanced with parsimony, justice in summarizing other philosophers balanced with hope in going beyond them. And therefore in substance he avoided the utilitarian pitfall, into which Hume gazed fondly and into which Bentham enthusiastically leapt, of reducing all other virtues to prudence only. 
Love was one of the Smithian virtues, but balanced with pluralism. In TMS the "amiable" Christianity of Hutcheson came in for criticism chiefly because it tended to suppose that "the mixture of any selfish motive, like that of a baser alloy, . . . took away altogether the merit that would otherwise have belonged to any action" (TMS, p. 302). According to the system of love-only "self-Iove was a principle which could never be virtuous in any degree or in any direction" (TMS, p. 303). Such a specialized version of Christian love violated the propriety of a balanced set of virtues. Smith would have al ready known that A ristotle admired philautia, proper regard for oneself. And he would have discovered had helooked into Aquinas, love-only violated Christian orthodoxy, too. Hutcheson's False Lemma, Smith noted, implies that “virtue must consist in pure and disinterested benevolence alone" (TMS, p. 302). The same fault infects Kant, with justice put in the place of love. Smith was a virtue ethicist, not like many of his contemporaries an ethical reductionist.

Smith's confining of attention to five virtues, then, avoided the dual errors of quantity in modern ethical thinking — too many virtues or too few. The other two errors are of quality and of object. Smith's obsolete virtue-ethical system avoided them as well.

The most prevalent error is that of quality, the reduction of ethics to taste, or rather to "mere" taste, viewed as analogous to a taste for chocolate ice cream. Though ancient, found for example in some Platonic characters, it has in recent times been articulated most insistently by the logical positivists and their descendents. The theory is called officially "emotivism," "the doctrine that all evaluative judgments and more specifically all moral judgments are nothing but expressions of preference" (Madntyre 1981, p. 11, his italics). Or as Hobbes wrote in 1651, “Good and evil are names that 
signify our appetites and aversions" (1651, I, Chp. 15, p. 82; and I, Chp. 6, p. 24). Most academics and other intel lectuals nowadays, without giving it much thought, adhere to the emotivist, chocolate-ice-cream theory. They view the ethical person as maximizing her utility function with respect to the doing of good deeds, just as she does in the eating of ice cream. No duty, love, faith, or persuasion carried weight. The sort of amiable, casuistic reasoning together that the virtue-ethical and rhetorical tradition recommends, the trading of "more or less good reasons," as the literary critic Wayne Booth put it, such as the stories of good or bad lives ranging from the Hebrew Bible and Plutarch to the latest movie, is spurned. No persuasion, please: we're positivists.

Economists in the centuries after Smith, and especially in the 20th century, led the attack by the secular clerisy against preaching the virtues. The economist Mark Blaug, for example, in many other respects a surprisingly sensible member of his profession, asserted in 1980 that "There are no ... methods for reconciling different normative value judgments-other than political elections and shooting it out at the barricades" (1980, pp. 132-33). By "methods for reconciling" he appears to mean air-tight proofs such as the Pythagorean Theorem, not the reasonable discourse of impartial spectators, what Smith called the "faculty of speech" by which "every one. . is practicing oratory on others thro the whole of his life" (WN, p. 25; Lectures on Jurisprudence (1762-63), p. 352; cf. TMS, p. 336). The economist Joseph Schumpeter of Vienna and Harvard had earlier expressed an ethical philosophy and a trivialization of language similar to Blaug's: “We may, indeed, prefer the world of modern dictatorial socialism to the world of Adam Smith, or vice versa, but any such preference comes within the same category of subjective evaluation as does, to plagiarize Sombart, a man's preference for blondes over 
brunettes." Thus al so Lionel Robbins of the London School of Economics: "If we disagree about ends it is a case of thy blood against mine--or live and let live, according to the importance of the difference, or the relative strength of our opponents. . .. If we disagree about the morality of the taking of interest..., then there is no room for argument" (Robbins 1932, p. 134).

The central dogma of modernism, Wayne Booth noted, is "the belief that you cannot and indeed should not allow your values to intrude upon your cognitive lifethat thought and knowledge and fact are on one side and affirmations of value on the other" (1974, p. 13). Booth instances Bertrand Russell as one in whom "passionate commitment has lost its connection with the provision of good reasons" (p. xi; and Chapter 2). (N ote by the way the self-refutation embodied in such a rule of method, that one should not say "should." As Russell himself found in another connection, selfreference leads to cycling self-contradiction. "All Cretans are liars," quoth the Cretan.)

Russell claimed to not allow values to intrude upon his cognitive life, which meant that he indulged his values without the check of good reasons. And so the mathematical philosopher applied low and sometimes no standards to his opinions about ethics and politics and economics. His friend Santayana describes Russell during the Great War exploiting his retentive memory without ethical reasoning: "This information, though accurate, was necessarily partial, and brought forward in a partisan argument; he couldn't know, he refused to know everything; so that his judgments, nominally based on that partial information, were really inspired by passionate prejudice and were always unfair and sometimes mad. Hewould say, for instance, that 
the bishops supported the war because they had money invested in munitions works" (Santayana 1943-53, p. 441).

We can't have reasonable ethical lives, the virtue ethicists like Smith claim, if we depend only on a narrow definition of reason. "But though reason is undoubtedly the source of the general rules of morality," Smith noted, without much optimism that "general rules" were themselves worth having, "it is altogether absurd and unintelligible to suppose that the first perceptions of right and wrong can be derived from reason" (TMS, p. 320). Such taste, however, is not "mere" in Smith, to be determined without education or reflection. It is rather the providing of good reasons, yielding "reason, principle, conscience, the inhabitant of the breast, the man within, the great judge and arbiter of our conduct" (TMS, p. 137).

The other characteristically modern error in thinking about ethics is an error of object. The error is more technical than the chocolate ice cream theory just described, and is committed especially by analytic philosophers venturing into ethics. It reduces ethics to matters of how you treat other people. That might seem to be no error. Surely ethics is about altruism? No, it is not, not only. Look back at the diagram, and note the ethical objects of self, of others, and of the transcendent. The good life will involve all three. A triple perfection, one might say.

For example, the philosopher Susan Wolf in a well-known essay, “M oral Saints,” adopts an exclusively public, social, altruistic definition of “virtue” (1982 [1997], p. 80, line 7, "improving the welfare of others or of society as a whole," among many other places--four times on p. 80, for example; on p. 81; p. 85, middle; taken back on p. 93, top, but then, “This approach seems unlikely to succeed'). In the style of many Anglophone 
philosophers she leaves out privately self-interested prudence as a virtue, and so lets her moral saints behave badly towards themselves. Showing its badness is Wolf's point, by a reduction to absurdity: moral saints are objectionable precisely because they care nothing for themselves. "If the moral saint is devoting all his time to feeding the hungry," Wolf observes, "then necessarily he is not reading Victorian novels, playing the oboe, or improving his backhand. ... A life in which none of these possible aspects of character is developed may seem a life strangely barren" (Wolf [1982] (1997, p. 81).

It's the Jewish-mother version of goodness: “Oh, don't bother to replace the bulb. I'Il just sit here in the dark." But the mother, after all, is God's creature, too, and her benevolence therefore should include a just benevolence towards herself. Being wholly altruistic, and disregarding the claims of that person also in the room called Self, about whose needs the very Self is ordinarily best informed, is making the same mistake as being wholly selfish, disregarding the claims of that person called Other. Smith of course agreed. It is the characteristically anti-paternal istic feature of his thought to assert that Self is best informed about Self's needs. Fleischacker observes: "That ordinary people could be trusted with their own decisions about what . . . to consume was one of the least acceptable propositions of $W N$, to the intellectuals and politicians of its day, and at the same time one of its most important, . . . insofar as it robbed merchants of a prime argument for government control" (2004, p. 89)

The ethical error is to ignore someone. Oddly, selflessness-note the word-is unjust, inegalitarian. "There is a manifest negligence in men of their real happiness or interest in the present world," said Bishop Joseph Butler in 1725. People are "as often unjust to themselves as to others" (Butler 1725, Sermon I, p. 371). The more optimistic 
Earl of Shaftesbury took in 1713 an evolutionary line to arrive at praise for such prudence:

the affection toward private or self-good, however selfish it may be esteemed, is in reality not only consistent with public good but in some measure contributing to it. . [It is] for the good of the species in general.... So far as being blamable in any sense, . . it must be acknowledged absolutely necessary to constitutea creature good.... No one would doubt to pronounce so if he saw a man who minded not any precipices which lay in his way, nor made any distinction of food, diet, clothing or whatever else related to his health and being.

Shaftesbury, Characteristics 1713 (1732), Vol. II, p. 13f; compare Vol. II, p. 18, "if the affection be...'

Prudence within a set of cultivated virtues is not self-centeredness.

Even very sensible philosophers want nowadays to deny such an obvious truth by reducing every virtue to improving the welfare of others or of society as a whole. In his last book Robert N ozick, who was most famous for his attempt to bring libertarian ideas traceable in part to Smith into political philosophy, tried to argue that "ethics exists because at least sometimes it is possible to coordinate actions to mutual benefit" (2001, p. 244; the next two quotations are from pp. 246 and 256). This is the economist's all-ye-need-to-know, the new welfare economics of the 1930s. Or: "Ethics arises when 
frequently or importantly there are situations offering opportunities for mutual benefit from coordinated activity." And a utilitarian, which N ozick tried not to be, would say that "since cooperation to mutual benefit is the function of ethics, the only thing that matters is . . . the size of the social pie."

But after 64 closely reasoned pages N ozick is left worrying that ethics must have something more. The reason he gets into trouble is that he makes that characteristically modern philosophical error of simply defining ethics as "concerning interpersonal relations" (2001, p. 248). In other words, his main argument has no place for the virtues of self-improvement or of devotion to a transcendent. It is a middle-level ethics, neither at the hope-faith-transcendent-love top or the temperance-self-interested-courage bottom, but aimed at a shallow conception of justice-only implemented with prudence. It is entirely about economics; that is to say, about "Pareto optimality," about mutually beneficial deals in the middle range. The ethical objects are the other people in the deal, not ever oneself or God.

But I said N ozick was sensible. And it is hard to imagine a more intellectually honest person. So occasionally he breaks into praise for the al ternative ethical objects, as though realizing uneasily that his reduction to prudent-but-procedurally-just deals has not sufficed. He distinguishes four "levels or layers of ethics," referring to a treatment in his semi-popular book of 1989, The Examined Life (2001, p. 280; 1989, pp. 212-215). The first, or lowest, is the mutual benefit on which N ozick spends most of his analytic effort in the 2001 book, Pareto optimality, the ethic of respect. The next is an ethic of responsibility, discussed also in his 1981 book, Philosophical Explanations (pp. 499-570). The next is an ethic of caring, N ozick's version of love, though again "caring" only about 
other people, not about oneself or God. And the fourth and highest is an ethic of Light, "truth, goodness, beauty, holiness," or in other words the ethics of faith, hope, and transcendent love (1989, p. 214f; his capitalization).

Nozick admits that he has no account of how the levels relate, or why he should al ways call the ethic of respect "basic'-except on the not unreasonable political grounds that it is the least controversial. He does not know the virtue ethicists. They arenever mentioned by this most ethically obsessed of the analytic philosophers. The two references to Bernard Williams in Invariances (2001) are on matters of metaphysics, not ethics. A ristotle as an ethical theorist is discussed only briefly; A quinas is not mentioned in any work of Nozick; nor are any other virtue ethicists (1981, pp. 515ff). Though he thinks his social ideas originate in Smith, he appears not to have read TMS with care. His 2001 book speaks of Smith's book on one occasion, as holding a theory of the "ideal observer," a misquotation placed in quotation marks-the phrase, dear Robert, is the "impartial spectator." (Note the shift registered in the error, by the way, between a humanistic metaphor of theatre to an anti-humanistic metaphor of observational science.) And the passage construes the notion in Smith as being about "moral" matters having to do with other people, not the self-shaping temperance that is the chief theme of TMS (2001, p. 288).

James Otteson has tried to place Smith in an evolutionary frame, a version of prudence-only along Nozickian lines, in which "over time, peoplefind that they can better satiffy their interests if they cooperate in certain ways" (2002, p. 295). "Rules about propriety and contracts are those that have proved to satisfy human interests most efficiently" (p. 296). "The goal whose attainment these exercises make more likely is 
mutual sympathy of sentiments" (p. 294). This seems to come at it the wrong way. Moral sympathy in Smith is the input, not the output, as can be judged from the organization of TMS: it starts with sympathy, sharply distinguishing it from selfishness. The output is the ethical person, for her own sweet sake, not for the sake of "better satisfying [her] interests." Interests are good, says Smith, since poverty is bad, and it was surely part of Smith's project to "detoxify the pursuit of wealth," as Griswold puts it (1999, p. 265). But in both TMS and (even) WN Smith roundly attacks better-satisfyinginterests as a final end of living.

Smith is also very fierce against rules and maxims, even "rules about propriety and contracts," unless the strict rules of procedural justice, as though he did know about Professor Kant's theorizing in far Köningsberg, and had a low opinion of it. I have noted his attacks on casuistry, which he understood as the giving of rules (Toulmin and Jonsen 1987 give it a more sympathetic reading). He says elsewhere that "the general rules of almost all the virtues ... are in many respects loose and inaccurate . . and require so many modifications that it is scarcely possible to regulate our conduct entirely by regard to them" (TMS, p. 174).

One is reminded (and so is Otteson: p. 268n20) of the most extreme of the evolutionary psychologists nowadays, such as Steven Pinker. Listen to Pinker in 1997 on the rationality of friendship: "now that you value the person, they should value you even more ... because of your stake in rescuing him or her from hard times ... This runaway process is what we call friendship" (Pinker (1997, quoted in Fodor (1998).

No, Steven, it is what we call self-absorption. The cognitive philosopher Jerry Fodor remarks of Pinker's onefactor theory: 
A concern to propagate one's genes would rationalize one's acting to promote one's children's welfare; but so too would an interest in one's children's welfare. Not all of one's motives could be instrumental, after all; there must be some things that one cares for just for their own sakes. Why, indeed, mightn't there be quite a few such things? Why shouldn't one's children be among them?

Fodor 1998

He quotes Pinker on the evolutionary explanation for why we humans like stories, namely, that they provide useful tips for life, as for example to someone in Hamlet's fix: "What are the options if I were to suspect that my uncle killed my father, took his position, and married my mother? Good question." Startlingly, Pinker does not appear to be joking here. It's funny, this "scientific" attempt to get along without sheer love, or sheer courage, or to get along without the aesthetic pleasure of stories reflecting faith and hope. The output, I say, is the ethical hero, the human with a conscience, the Human Within, not pleasures or interests that would satisfy a cat.

All right. Smith analyses good and bad not as a specialized prudence or justice or temperance but as a proper balance among five of the seven A quinian virtues. We will not grasp his argument if we insist on making it lie down on a Kantian or a utilitarian or a natural-rights or even a social-contractual bed, as analytic philosophers amateur and professional have long tried to do. Smith was a virtue ethicist first and last.

But something is missing. In choosing his five virtues, Smith drops the two transcendent virtues of hope and faith, with the transcendent version of love going 
beyond love for people, agape as against the philia or eros in the precise Greek. There is no question that Smith realized what hewas doing. He knew perfectly well that hope and faith and agape were primary virtues in Christian thought-this would have been clear even in the secondary descriptions of scholastic thought-though as I've said he may have lacked a direct understanding of Aquinas" role in the construct. But if someone lacks "strengths that forge connections to the larger universe and provide meaning," in Peterson and Seligman's words, she does not have a fully human life. That cat again. Or as the Anglican theologian Richard Hooker put it in 1593, “M an doth seek a triple perfection: first a sensual .... then an intellectual. ... Man doth not seem to rest satisfied .... For although the beauties, riches, honor s, sciences, virtues [which means "power" here], and perfections of all men living, were in the present possession of one; yet somewhat beyond and above all this there would still be sought and earnestly thirsted for" (First Book, IX, 4, pp. 205-206).

The reason Smith neglected hope and faith and agape is not obscure. He shared with Enlightenment figures such as Hume and Voltaire an aversion to any alleged "virtue" that could be seen as conventionally religious. Hope and faith looked to advanced thinkers in the $18^{\text {th }}$ century horribly conventionally religious, and anyway dispensable. Let us build a new world free from religious superstition, they cried, free from the wars of sects, free from the meddling of priests and dominies. Let us dispense with "hope" and "faith," and establish a new. . . uh ... faith on the ... uh. . . hopes for reason and propriety.

The Christianity that Smith opposed was the rigid Calvinism still influential in Scotland at the time, no longer ascendant but able (with some hel p from the benevolent 
Francis Hutcheson) to keep atheists like Hume out of the universities. And he opposed too Catholicism that could in France still warrant the conviction of a Protestant, Jean Calas, alleged on slender evidence in 1762 to have murdered his suicidal son to prevent the son's conversion to Catholicism. Such religious fanatics, with which Scotland had recently had so much experience, impute "even to the great Judge of the universe. . . all their own prejudices.... Of all of the corrupters of moral sentiments. . faction and fanaticism have always been by far the greatest" (TMS, p. 156). Smith wanted, as did Hume and Kant and Bentham and Locke for that matter, to bring ethics down to earth: “The most sublime speculation of the contemplative philosopher can scarce compensate the neglect of the smallest active duty'(TMS, p. 237). One can hear him induding the theologian and other advocates for the transcendent in that phrase "contemplative philosopher." Compare Hume's sneering at "divinity or school metaphysics" and the "monkish virtues." Thus Hobbes without God, Spinoza without God, Vico without God, Hume without God, Kant without God. No monkish virtues of hope and faith, please: we're Enlightenment philosophers.

In their official Christian vestments, that is, hope and faith were often unwelcome in the clubs and salons of the philosophes and, later, especially after 1848, in the ateliers and universities of the European and especially the Continental intelligentsia. So still. Even the excellent Rosalind Hursthouse seems embarrassed by the Transcendent Two. Her lucid exposition of virtue ethics in 1999 mentions in its index the virtue of love 90 times under various headings: benevolence, charity, compassion, generosity, kindness, loyalty, friendship (Hursthouse, Virtue Ethics (1999, index; I am counting multiple pages at their total: thus "benevolence, Humean, 99-102" 
counts as four pages in the sum). Loyalty and friendship have perhaps an element of faith in them, though note the absence of the transcendent part of love itself, agape. The virtue of justice, the male philosophical obsession, she mentions 28 times. Temperance (and self-control) 18. Courage 24 (more male obsession). Moral wisdom, that is, phronesis, that is, prudence, which in Aquinas" analysis underlies all the virtues, 26 times. The typically modern and bourgeois philosopher's virtue of honesty (out of justice, temperance, courage, and faith) 22 times. That covers the Smithian pentad.

But where are the other two, sacred hope and sacred faith, and the transcendent part of love? Hursthouse ends her book with an appeal to "Keep hopealive." Her only other mention of hope and faith is a page attacking the so-called virtue of piety, which combines them, as irrational, not characteristically human, “based on a complete illusion" from an atheist's point of view (Hursthouse 1999, p. 232f; compare 218: “But what could this fifth end be?'). Onewonders, though: is the physicist's pious but entirely atheistic faith in the orderliness of nature, which Smith and Hume and Kant buried in their magic adjective "natural," and which Hursthouse elsewhere notes is essential for a scientific world view, therefore also "irrational'? Is science, then, as religious faith is in her account, “based on a complete illusion'? Hursthouse's own project-based on the pious hope that the virtues can be justified piecemeal from within a cultural set of them-is likewise undercut.

We humans cannot get along without transcendence, which is faith in a past, hope for a future, love for an ideal, justified by Larger Considerations. If we don't have faith, hope, and love for God, we'll substitute Art or Science or National Learning. If we don't have Art or Science or National Learning or Anglicanism we'll substitute 
fundamentalism or the Rapture. If we don't have fundamentalism or the Rapture or the Iocal St. Wenceslaus parish we'll substitute our family or the rebuilt antique car. Faith, hope, and transcendent love are a consequence of the human ability to symbolize, a fixture of our philosophical psychology.

We might as well acknowledge transcendence in the way wetalk and think about ethics, if only to keep watch on it and prevent it from doing mischief, as did once a Russian hope for the socialist Revolution and as does now a Saudi Arabian faith in an Islamic past. In the century after Smith and during Romance the virtues of hope, faith, and transcendent came back into the Western discussion with a vengeance, in the form of a forward-looking hope for social ism and in the form of a backward-looking faith in nationalism, justified by a self- and other-sacrificing love for the transcendent. Whence 1914 and 1917 and national socialism and all our woe. The Bulgarian-French critic, Tzvetan Todorov warns that "democracies put their own existence in jeopardy if they neglect the human need for transcendence" (2000, p. 32). Michael Ignatieff put it well: “The question of whether ... the needs we once called religious can perish without consequence... remains central to understanding the quality of modern man's happiness'( 1984, p. 21). Evidently the answer is no. There are consequences and there will be more. That is not a reason to return to the older sureties, although I do warmly recommend progressive Episcopalianism. But it is a reason to take seriously the transcendent in our imagined lives. Adam Smith's error was the error, and the glory, of the Enlightenment, trying to liberate us from transcendence.

But anyway the hope and faith and transcendent love slip back into Smith, as into Kant and the rest, although by the back door unobserved. The Impartial Spectator, 
or the Kantian or even the Benthamite equivalent, are not merely behavioral observations about how people develop ethically. They are recommendations. Recommendations depend on faith and hope and transcendent love, articulated from the identity of an urbane resident of Edinburgh, for example, hopeful for a rather better society, loving sweetly the imagined result. As Fleischacker notes, “When we ask after the "nature" of human beings we are looking for what human beings "really" want, beneath the surface trappings. ... Human nature al ways includes what people aspire to, for Smith; it is never reduced [as in the economist's version of utilitarianism] to the desires they merely happen to have" (2004, pp. 61, 63).

And how was this faithful and loving hope, this aspiration to full humanity, to be achieved? Through cultivating the seven virtues—or Smith's five, with hope and faith and transcendent love knocking softly at the back door.

\section{References}

Anscombe, G. Elizabeth M. (1958), “Modern Moral Philosophy," Philosophy, 33, 1-19, reprinted as pp. 26-44 in Crisp and Slote (eds) (1997), Virtue Ethics. 
Aquinas, St. Thomas (c. 1269-1272), Disputed Questions on Virtue [Quaestio disputata de vertibus in commune and Quaestio. . cardinalibus], Translation and preface Ralph Mclnerny (ed.) (1999), South Bend, Indiana: St. Augustine's Press.

Aquinas, St. Thomas., (c. 1270), Treatise on the Virtues [Summa Theologiae, First Half of the Second Part, questions 49-67], John A. Oesterle (ed.) (1984), N otre Dame, Indiana: University of Notre Dame Press.

A ristotle (c. 330 BC), Nicomachean Ethics, H. Rackham (ed.) (1934), Cambridge: Harvard University Press.

Bentham, Jeremy (1789), A Fragment on Government, with an Introduction to the Principles of Morals and Legislation, W. Harrison (ed.) (1948), Oxford: Basil Blackwell.

Blaug, Mark (1980), The Methodology of Economics: Or, How Economists Explain, Cambridge: Cambridge University Press.

Booth, Wayne C. (1974), Modern Dogma and the Rhetoric of Assent, Chicago: University of Chicago Press.

Brown, Vivienne(1994), Adam Smith's Discourse: Canonicity, Commerce, and Conscience, London: Routledge.

Buchanan, James and Gordon Tullock (1962), The Calculus of Consent, Ann Arbor: University of Michigan Press.

Butler, Joseph, Bishop (1725, 1736), Fifteen Sermons, pp. 335-528 in The Analogy of Religion and Fifteen Sermons, reprinted (n.d.), London: The Religious Tract Society. 
Cicero, Marcus Tullius (44 BC), De officiis (Concerning Duties), W. Miller (trans.) (1913), Cambridge: Harvard University Press.

Copleston, Frederick (1959), A History of Philosophy, Vol. V, Modern Philosophy: The British Philosophers from Hobbes to Hume, London: Burns and Oates.

Crisp, Roger and Michael Slote (eds) (1997), Virtue Ethics, Cambridge: Cambridge University Press.

Evensky, Jerry (2005), Adam Smith's Moral Philosophy: A Historical and Contemporary Perspective on Markets, Law, Ethics, and Culture, Cambridge: Cambridge University Press.

Finnis, John M. (1980), Natural Law and Natural Rights, Oxford: Clarendon Press.

Fitzsgibbons, Athol (1995), Adam Smith's System of Liberty, Wealth, and Virtue: The Moral and Political Foundations of The Wealth of Nations, Oxford: Clarendon Press.

Fleischacker, Samuel (2004), On Adam Smith's Wealth of Nations: A Philosophical Companion, Princeton: Princeton University Press.

Foot, Philippa (1978), “Virtues and Vices, “ pp. 1-18 in Foot, Virtues and Vices and Other Essays in Moral Philosophy, Berkeley and Los Angeles: University of California Press.

Frankfurt, Harry (2004), The Reasons of Love, Princeton: Princeton University Press.

Griswold, Charles L., Jr. (1999), Adam Smith and the Virtues of Enlightenment, Cambridge: Cambridge University Press. 
Haakonssen, Knut (1981), The Science of a Legislator: The Natural Jurisprudence of David Hume and Adam Smith, CambridgeUniversity Press.

Hariman, Robert (2003), “Theory without Modernity, “ pp. 1-32 in Hariman (ed.), Prudence: Classical Virtue, Postmodern Practice, University Park: Pennsylvania State University Press.

Hobbes, Thomas (1651), Leviathan, Everyman Edition (1914), London: J. M. Dent and New York: E. P. Dutton.

Hont, Istvan and Michael Ignatieff (1983), "N eeds and Justice in the Wealth of Nations," in Hont and Ignatieff (eds), Wealth and Virtue, Cambridge: CambridgeUniversity Press.

Hooker, Richard (1593), On the Laws of Ecclesiastical Polity, Vol. I (Books I - IV), Everyman Edition (1907), London: J. M. Dent.

Hursthouse, Rosalind (1999), On Virtue Ethics, Oxford: Oxford University Press.

Hutcheson, Francis (1725), Inquiry into the Origins of our Ideas of Beauty and Virtue, in Two Treatises, A. Garrett (ed.) (2002), Indianapol is: Liberty Fund.

Hutcheson, Francis (1747), A Short Introduction to Moral Philosophy in Three Books, containing the Elements of Ethics and the Law of Nature, W. Leidhold (ed.) (2004), Indianapolis: Liberty Fund.

Ignatieff, Michael (1984), The Needs of Strangers, reprint (2001), New York and London: Viking Penguin Books. 
Ignatieff, Michael (1998), Isaiah Berlin: A Life, New York: Metropolitan.

Kant, Immanuel (1785), Grounding for the Metaphysics of Morals, trans. James Ellington (1993), Indianapolis: Hackett.

Knight, Frank (1923), “The Ethics of Competition, “ Quarterly Journal of Economics, reprinted as pp. 33-67 in Knight (1935) The Ethics of Competition, reprinted (1997) New Brunswick, NJ: Transaction Publishers.

Maclntyre, Alasdair (1981), After Virtue: A Study in Moral Theory, Notre Dame: University of Notre Dame Press.

Mandeville, Bernard (1705, 1714, 1723, 1728), The Fable of the Bees, F. B. Fay (ed.) (1924), reprint (1988), Indianapolis: Liberty Fund.

Marshall, David (1986), The Figure of Theater: Shaftesbury, Defoe, Adam Smith, and George Eliot, N ew York: Columbia University Press.

McCloskey, Deirdre N. (2006), The Bourgeois Virtues: Ethics for an Age of Commerce, Chicago: University of Chicago Press.

North, Helen F. (1973-74), “Temperance (Sōphrosynē) and the Canon of the Cardinal Virtues, “ pp. 365-378 in Vol. 4 of P. P. Wiener (ed.), The Dictionary of the History of Ideas: Studies of Selected Pivotal Ideas, N ew York: Charles Scribner's Sons, N ew York.

N ozick, Robert (1974), Anarchy, State, and Utopia, N ew York: Basic Books.

N ozick, Robert (1981), Philosophical Explanations, Cambridge: Harvard University Press. 
N ozick, Robert (1989), The Examined Life: Philosophical Meditations, New York: Simon and Schuster.

N ozick, Robert (2001), Invariances: The Structure of the Objective World. Cambridge: Harvard University Press,

N ussbaum, Martha C. (2006), Frontiers of Justice: Disability, Nationality, Species Membership, Cambridge: Harvard University Press.

Nussbaum, Martha (1986), The Fragility of Goodness: Luck and Ethics in Greek Tragedy and Philosophy, Cambridge: Cambridge University Press

Orwell, George (1940), “Charles Dickens, “ reprinted as pp. 135-185 in Orwell, Essays, John Carey (ed.) (2002), New York: Knopf.

Otteson, James R. (2002), Adam Smith's Marketplace of Life, Cambridge: Cambridge University Press.

Peterson, Christopher and Martin E. P. Seligman (2004), Character Strengths and Virtues: A Handbook and Classification, Oxford: Oxford University Press.

Raphael, D. D. and A. L. Macfie (1976), “Introduction,” Adam Smith, The Theory of Moral Sentiments, Glasgow Edition, Raphael and Macfie, eds. Indianapolis: Liberty Classics, 1976, 1982.

Rawls, John (1971), A Theory of Justice, Cambridge: Harvard University Press.

Robbins, Lionel (1932), The Nature and Significance of Economic Science, London: Macmillan. 
Rothschild, Emma (2001), Economic Sentiments: Adams Smith, Condorcet, and the Enlightenment, Cambridge: Harvard University Press.

Santayana, George (1943-53), Persons and Places, Vol. 1 of The Works of George Santayana (1986), Cambridge, Mass.: MIT Press.

Shaftesbury, Anthony A shley Cooper, $3^{\text {rd }}$ Earl, $(1713,1732)$, Characteristics of Men, Manners, Opinions, Times, 6th 1732, D. Den Uyl. (ed.) (2001) Indianapolis: Liberty Fund.

Singer, Peter (1993), Practical Ethics, $2^{\text {nd }}$ ed., Cambridge: Cambridge University Press.

Stigler, George (1975), "Smith's Travels on the Ship of State," in A. Skinner and T. Wilson (eds), Essays on Adam Smith, Oxford: Clarendon Press,

Strauss, Leo (1953), Natural Right and History, Chicago: University of Chicago Press.

Todorov, Tzvetan (2000), Hope and Memory: Lessons from the Twentieth Century, trans. David Bellos (2003), Princeton: Princeton University Press.

Toulmin, Stephen and Albert Jonsen (1987), The Abuse of Casuistry: A History of Moral Reasoning, Berkeley and Los Angeles: University of California Press.

Van N orden, Bryan W. (2004), "The Virtue of Righteousness in Mencius," pp. 148-182 in Kwong-Loi Shun and David B. Wong (eds), Confucian Ethics: A Comparative Study of Self, Autonomy, and Community, Cambridge: Cambridge University Press.

Winch, Donald (1978), Adam Smith's Politics: An Essay in Historiographic Revision, Cambridge: Cambridge University Press. 
Wolf, Susan (1982), “Moral Saints, “ Journal of Philosophy 79: 419-439, reprinted as pp. 7998 in Crisp and Slote (1997), Virtue Ethics. 